\title{
AVALIAÇÃO DA CAPES: CONTRIBUIÇÃO PARA O APRIMORAMENTO DOS PERIÓDICOS DE ENFERMAGEM?
}

\author{
Joel Rolim Mancia ${ }^{1}$
}

Os pesquisadores brasileiros da área de enfermagem precisam divulgar o conhecimento produzido na pós-graduação. É um compartilhar com a comunidade científica e se concretiza, principalmente, com a exposição desta produção nos congressos e em outros eventos afins. No entanto, a publicação impressa dos resultados de pesquisa se dá nas revistas de enfermagem e estas são a memória da ciência: são suas páginas que preservam o conhecimento e o difundem, inclusive, no âmbito internacional.

A maioria de nossos periódicos foram criados nas universidades e como tal, se comparados com outros, gerados fora deste espaço, têm condições privilegiadas para sua consecução como infra-estrutura, recursos humanos e recursos financeiros. Mesmo com estas condições têm de superar problemas de circulação pouco abrangente, muitas vezes restrita ao espaço institucional, expondo a produção científica a pouca crítica.

Por outro lado, os periódicos criados nas sociedades científicas e de categoria profissional, têm aspectos muito positivos como diversidade na autoria dos trabalhos, circulação mais ampla, de maneira que é mais visível à crítica e dispõe tratamento favorável dado pelos órgãos financiadores. No entanto, apresentam problemas crônicos, como infra-estrutura deficitária, recursos humanos e financeiros escassos, dependendo sua impressão quase sempre de trabalho voluntário de seus dirigentes.

A CAPES que a partir de meados de 90, intensificou seu projeto de qualificação dos programas de pós-graduação, com vistas a uma inserção internacional, impulsionou, velozmente, os editores destes periódicos, tanto aqueles sediados nas universidades como os que são divulgados pelas sociedades de categoria profissional o que provocou uma competição, que tem contribuído para a qualificação dos veículos de divulgação científica da enfermagem brasileira.

Embora possamos afirmar que a partir de 2000 tenha havido uma melhora em alguns periódicos ao se adequaram aos critérios estabelecidos pela CAPES, é preciso destacar que tais critérios não foram suficientes para gerar uma mudança de perfil na maioria das publicações.

Numa avaliação dos periódicos melhor classificados, pode-se inferir que somente três conseguiram satisfazer as exigências da CAPES se considerarmos, apenas, os critérios essenciais.

Neste momento, em que a Comissão de Avaliação Continuada da CAPES torna público o resultado do QUALIS-Enfermagem 2002 com a classificação dos periódicos de enfermagem, pode-se dar continuidade às discussões sobre os critérios utilizados e sobre a capacidade e potencial de adequação dos periódicos.

Uma discussão construtiva que envolve os dirigentes dos periódicos, a CAPES, a pós-graduação e a ABEn deverá acontecer em encontro programado por ABEn/CAPES para 11 de novembro de 2002, no 54 Congresso Brasileiro de Enfermagem, em Fortaleza. 